\title{
Financial Instruments' Disclosure in Compliance with IFRS 7: The Portuguese Companies
}

\author{
Francisco Leote ${ }^{1, ~ *}$, Clarisse Pereira ${ }^{1}$, Rui Brites ${ }^{2}$, Teresa Godinho ${ }^{1}$ \\ ${ }^{1}$ Department of Accounting and Finance, Business School of Polytechnic Institute of Setúbal, Setúbal, Portugal \\ ${ }^{2}$ Department of Management, Business School of Polytechnic Institute of Setúbal, Setúbal, Portugal

\section{Email address:} \\ francisco.leote@esce.ips.pt (F. Leote), clarisse.pereira9@gmail.com(C. Pereira), rui.brites@esce.ips.pt (R. Brites), \\ teresa.godinho@esce.ips.pt (T. Godinho) \\ *Corresponding author
}

\section{To cite this article:}

Francisco Leote, Clarisse Pereira, Rui Brites, Teresa Godinho. Financial Instruments' Disclosure in Compliance with IFRS 7: The Portuguese Companies. International Journal of Accounting, Finance and Risk Management. Special Issue: Perspectives on Risk Management and Impact on Sustainability of Companies. Vol. 5, No. 1, 2020, pp. 52-61. doi: 10.11648/j.ijafrm.20200501.15

Received: December 31, 2019; Accepted: January 6, 2020; Published: March 10, 2020

\begin{abstract}
The constant changes in the business context and international relations have led companies to be provided with financial reporting with useful information, including their relevance, comparability and harmonization as required by International Financial Reporting Standards (IFRS). This study analyzes the level of disclosure of derivative financial instruments from companies in the PSI20 stock index, in the Euronext Lisbon stock exchange, according to requirements of IRFS 7. A disclosure index was created, based on the reports and accounts of companies in the period 2015-2017. To analyze the evolution of the disclosure level according to companies' characteristics (dimension, profitability, share price and auditor type), we applied a cluster analysis. The results show a high level of disclosure. This evidence may be related to the mandatory adoption of IAS / IFRS and may also reflect companies' greater concern in disclosing this type of information due to the negative impact that the global financial crisis has had on corporate performance in general. The dimension is the variable that affects disclosure. That is, there is a tendency to, the higher the company the higher the level of disclosure. However, the results show that smaller companies also have high levels of disclosure. This may be associated with greater or lesser quantity or value of derivative financial instruments used.
\end{abstract}

Keywords: Financial Instruments, Disclosure, IFRS 7

\section{Introduction}

Increasing relations at international level and constant business context change led companies to have financial statements with useful information, covering its comparability and harmonization, as required by international financial reporting standards (IFRS).

In everyday life companies are exposed to the most diverse risks and most use financial instruments, more specifically derivatives, to minimize the impact.

IFRS 7 [1] is the main instrument for this study. This standard aims to increase the quality and quantity of information disclosed by companies.

The main objective of the work is based on the analysis of information disclosure level about derivative financial instruments from companies belonging to the Euronext
Lisbon stock index - PSI 20 (it's a Portuguese Stock Index that brings together the twenty largest companies), during the period 2015-2017. This work therefore aims to address the following question: "Do Portuguese companies meet the requirements of IFRS 7 about information disclosure on financial instruments?"

Thus, through the analysis of the information disclosed by the companies in its Reports and Accounts, we created the variable Disclosure Index (ID), in compliance with the requirements of IFRS 7. Por conseguinte, pretende-se determinar quais os fatores que influenciam o nível de informação que é divulgada.

In a second phase, we intend to study the behavior of companies' dissemination level throughout the period under analysis, through cluster analysis. depending on disclosure determinants. 
The main obtained results show a high compliance with IFRS 7 mandatory disclosure requirements. There is a positive relationship between ID and business size, as well as an ID value stability for most companies over the period under review.

In addition to this introduction, this work consists of four more sections. In section 2 we base the work, with reference to the accounting regulation and the literature on dissemination of information about financial instruments. In section 3 we describe methodology, while in section 4 we present and discuss the results. Later, we describe the main conclusions.

\section{Theoretical Foundation}

\subsection{Information Disclosure on Financial Instruments}

Given the constant change to which companies are subject today, obtaining and disseminating information is increasingly important, as it is essential for decision-making.

Our company society is governed based on firm and useful information and it is therefore important that it is available to users and stakeholders, so that everyone can access it making, thus, increasingly aware decisions.

Financial reporting serves to make the information contained in the financial statements useful to users and to do so it must comply with four qualitative characteristics: comprehensibility, relevance, comparability and finally reliability.

IAS/IFRS arise not only to increase the information disclosed by companies, but also so that users, when accessing such information, may have access to a set of risks that may be associated with a particular subject.

Thus, one of the main objectives of the disclosures required by IFRS 7 is the provision of information that enables user analysis, not only of the meaning of financial instruments for the financial position, but also of the company's performance; and the nature and size of the risks inherent to using financial instruments and how the company manages the risks.

The information disclosed by companies, in addition to being important to assist decision-making in an uncertainty scenario, also have economic consequences, in a context of wealth distribution and risk sharing; consumption and investment; allocation of resources among companies; amounts allocated to production, certification, disclosure, processing, analysis and reports interpretation; of the amounts made available for regulation and research [2].

In June 2000, in order to make Europe more competitive in the face of a constantly growing global market, some measures were approved by the European Union, including the adoption of IAS/IFRS.

The first regulations have thus emerged in order to establish a set of rules and standards that would allow transparency, clarity and comparability of financial statements.

Regulation (EC) In 1606/2002[3] the European Parliament provided for the implementation of IAS/IFRS, in order to promote the implementation of an action plan aimed at comparability and clarity of financial statements.
In accordance with Article 4, all companies with publicly traded securities must, since 1 January 2005, draw up their consolidated financial statements in accordance with IAS/IFRS.

Regulation (EC) No 1725/2003 [4] aimed at adopting the generality of IAS/IFRS, except The IAS 32- Financial Instruments: Disclosure and Presentation, IAS 39- Financial Instruments: Recognition and Measurement and also interpretations related to some SIC (Standing Interpretations Committee). Regulation (EC) No 1864/2005 amended Regulation (EC) No 1725/2003 with the aim of ensuring and recognizing the importance of adopting IAS 32 and IAS 39 standards by the European Union, as the number of amendments introduced in these regulations was significant.

However, Regulation (EC) No 1725/2003 was repealed and replaced by Regulation (EC) No 1126/2008 [5] on 3 November 2008, strengthening the adoption of IAS/IFRS.

Currently, IAS 32, IAS 39, IFRS 7 and IFRS 9 currently regulate accounting treatment and financial reporting of derivative financial instruments in companies in the European Union.

IFRS 7 aims to ensure that companies, when preparing their financial statements, disclose useful information to stakeholders. Companies should disclose information enabling stakeholders to assess the importance of financial instruments for the financial positioning and performance of the company and also to analyze the risks to which it is exposed, as to its nature, extent and management, during the period elapsed and reporting date.

The principles that make up IFRS 7 are added to the principles described in IAS 32 and IFRS 9, which respectively establish financial assets and liabilities recognition and measurement and presentation. Companies and financial instruments are covered by the standard, exception made for those that have its own legislation, as is the case with companies holding in joint ventures, associated or in subsidiaries, financial instruments, bonds and other. Considering financial instruments' disclosure requirements by classes, each company shall group them into appropriate classes, taking into account the nature of information disclosed as well as its characteristics. Thus, each company shall disclose adequate and sufficient information that allows greater coherence with the principles or lines of items described aboves.

In general, and in accordance with IAS 1, companies should publicize the accounting policies relevant to the understanding of financial statements, the measurement basis adopted in the preparation of financial statements and other accounting policies used in their preparation. Thus, IFRS 7 provides that disclosures made by companies about derivative financial instruments, have a qualitative and quantitative content.

About coverage accounting, the regulatory provides specific provisions which should be included in company's reports. For each type of risk coverage, the company discloses a description, exposing coverage financial instruments and fair values, as well as the nature of the risks to be covered.

In the case of fair value, it provides that companies group in 
classes its financial assets and liabilities, disseminating the fair value of each, allowing comparison with carrying amounts.

It should be noted that, in the event that the company performs a sensitivity analysis, it should disclose to each type of market risk, in order to make known how changes associated with the relevant risk variable affect profits, losses and equity.

\subsection{Derivative Financial Instruments Disclosure}

In the financial literature we find studies about derivative financial instruments, whether in terms of disclosure, risk coverage or determinants for their use or disclosure.

Regarding derivative instruments' disclosure, we can find some studies with different perspectives, since the object of study is framed in different periods and economic realities.

Thus, Marshall and Weetman [6] examined the level of disclosure about foreign exchange risk operations, policies used for their management, through derivative and non-derivative financial instruments, in the United Kingdom (UK) and the United States (USA). These authors also studied the inequality of information between managers and other stakeholders. The study focused on 30 companies from each country in 1998. The results showed UK companies reaching an index of around $46 \%$, with a higher disclosure rate than U.S companies, which reached approximately $39 \%$ of the index.

The authors then concluded that, in fact, the regulation was not being fully fulfilled, and in the UK predominated disclosures associated with risk coverage through non-derived financial instruments, and measures by the Corporate Government. Instead, in U.S. companies, information disclosure was associated with risk coverage through the use of derivative financial instruments. Finally, with regard to inequality of information between users and managers, they concluded that less information was disclosed in companies with greater risk exposure.

Darós, Borba and Júnior [7] analyzed compliance with financial instruments derivative required disclosure on 32 Brazilian companies, listed on the stock exchange and also audited by one of the four largest audit and consulting companies (Big Four ${ }^{1}$ ), in 2005.

Through this analysis, they could conclude that a significant part of the companies studied did not present sufficient and clear information regarding the use of derivative financial instruments, as required by the Brazilian regulator ${ }^{2}$. In view of this poor disclosure of information on derivative financial instruments, external companies that audited these companies have demonstrated a passive orientation [7].

Lemos and Rodrigues's study [8], on Portuguese companies listed on Euronext Lisbon, analyzed the degree of disclosure of derivative financial instruments in 2001 and 2004.

\footnotetext{
${ }^{1}$ Big Four- Term used to name the four largest audit and consulting companies at international level. Of these four companies are part of Deloitte, Ernst \& Young, KPMG and PricewaterhouseCoopers (PwC). http://lexicon.ft.com/Term?term=big-four consultado on 13/03/2018. 2 Normative Instruction 235 of the Securities and Exchange Commission.
}

The results showed that only $50 \%$ of the companies reported information on transactions in the derivatives markets. There was an increase in the number of mentions of derivative financial instruments in their Reports and Accounts from 397 mentions in 2001 to 669 in 2004. Lemos and Rodrigues [8] mentioned the existence of a positive relationship between the type of company and the number of references or mentions to derivative financial instruments in 2001, which means that, in the case of financial firms, there was a greater tendency towards increased mentions, unlike non-financial enterprises. This scenario was reversed in 2004.

Finally, the authors mentioned that, despite the increase between the two periods, information disclosure about this type of financial instruments was still insufficient, adding that due to the obligation to adopt IAS 39 the following year (2005), in the preparation of the consolidated financial statements, there would be a scenario with significant differences in relation to the economic years studied.

In the study by Lemos, Rodrigues and Ariza [9] the central objective was the analysis of the determining factors of the level of dissemination of information about derivative instruments in Portuguese companies. In this way, they studied all the companies listed on Euronext Lisbon in 2004.

Based on a multivariate analysis, they found that only the size of the company proved to be a determining factor for dissemination. However, after the application of a univariate analysis, they concluded that the factos external auditor (if the external auditor is part of one of the Big Four), indebtedness level, existence of stock plans and activity sector are determining factors in the level of information disclosure on derivative financial instruments.

Resende [10] in his study, analyzed the main determinants in the fulfillment of disclosures by companies listed in Portugal, required by IFRS 7.

From the analysis to 35 companies listed on Euronext Lisbon in the period 2010 to 2012, he concluded that factors such dimension, temporary differences between accounting and taxation, including deferred taxes and the use of passive financial instruments were decisive in information disclosure on derivative instruments.

In summary, the literature points to a low level of financial disclosure on derivative instruments. Factors such as external auditor, level of indebtedness, among others are pointed out as determinants of the level of disclosure, and the dimension factor is the most mentioned.

\section{Methodology}

The main objective of this study is to analyze the information disclosure level about the derivative financial instruments of the companies that make PSI 20, in the period 2015-2017.

To carry out the study we looked at the 17 companies that are part of Euronext Lisbon's PSI 20 index, since companies with a strong presence in the Portuguese economy. To a great extent, they use derivative financial products in their 
transactions. Thus, there is a higher probability of presenting disclosure, not only on risk exposure, but also about the financial products used in the coverage of this risk.

The companies considered in the study were Altri, Corticeira Amorim, CTT, EDP, EDP Renováveis, Galp Energia, Ibersol, Jerónimo Martins, Mota-Engil, The Navigator Company, NOS, Pharol, F. Ramadas, REN, Semapa, Sonae Capital, Sonae SGPS.

\subsection{Disclosure Index}

In this study we chose to create Disclosure Indices (ID) per company, with reference to the requirements of IFRS 7 (Nunes, 2014; Lemos et al., 2009) to quantify the level of disclosure of companies on derivative financial instruments (Appendix 1). For the creation of ID collect the data through content analysis to the Company Reports and Accounts.

The collection of this information made it possible to create the variable ID, through the following formula $[11,12,9]$ :

$$
I D_{i}=\sum_{j=1}^{e} e j / e
$$

In what, $I D_{i}$ represents the company's $i$ disclosure index; $e j$ the component under analysis, in the case of a dichotomous variable with value 1 if the company discloses information about component and value 0 if it does not disclose information about the component and represents the maximum number of components ( $\max .=37)$.

\subsection{Determinants of Disclosure Level (Independent Variables) and Hypotheses Definition}

For the analysis of the determinants of the ID we used the independent variables "Dimension", "Profitability", "Quotation" and "Auditor Type". Bivariate analysis is a statistical technique that allows the evaluation of the relationship between two variables and is one of the most used techniques when we are facing quantitative analyses.

In this study we applied the Spearman Correlation Coefficient, because it is more robust for smaller samples and also because it does not present a sensitivity to the presence of significant outliers [13]. In this way, we looked at the existence of correlations between independent variables and the level of information disclosure (ID), from 2015 to 2017.

For the formation of independent variables, we collected financial data in the Iberian Balance Sheet Analysis System (SABI) database.

The dimension of the company is indicated as a determining factor in the level of information disclosure and has been the most widely used independent variable in studies, such as Giraldo-Prieto, Uribe, Bermejo and Herrera [14], Moura, Dagostini, Theis and Klann [15] and Monteiro [12].

Larger companies, in general, are more likely to perform derivative operations [14]. These are also the companies that are most exposed, as they attract greater attention from investors and, for that reason, they have to ensure their credibility and confidence [15].

Authors such as Lemos, Rodrigues and Ariza [9], Hassan [16], Monteiro [12] and Nunes [17], used in their study, as a way of assessing the size of the company, the total asset. In this study, Dimension variable will be represented by each company's total value of the asset, in each year.

Profitability is another of the variables reported in Hassan [16], Malachi \& Zambra [18] and Lemos, Rodrigues and Ariza [9] as a determining factor in information disclosure level. To measure profitability, Lemos, Rodrigues and Ariza [9], they used the Return on Equity Ratio (ROE) and the Return on Assets ratio (ROA).

Ali, Ahmed and Henry [19] claim that companies with a higher profitability will tend to disclose more transparently and in detail the necessary information in order to add value. Hassan [16], for profitability, used the relationship between the profit before taxation and the total asset, like GiraldoPrieto, Uribe, Bermejo and Herrera [14].

Birt, Rankin and Song [20] point out that companies with greater leverage tend to be more exposed to financial risk and, for that reason, motivated to disclose information about derivative instruments.

For the present study, the ratio to be used to analyze the independent variable Profitability will be only the Equity Profitability:

$$
\text { ROE=Net Income / Equity }
$$

According to Lan, Wang and Zhang [21] the type of auditor has a significant impact on the market, that is, financial reports that are audited by renowned auditors (e.g. Big four) are recognized as of higher quality and credibility.

Chalmers and Godfrey [11] argue that, in view of any negative effects caused by transactions on derivatives markets, it is essential that audit firms with a significant market position adopt appropriate strategies adapted to derivative instruments and encourage audited companies to disclose information about this type of operations.

In view of the literature review, there is expected to be a positive relationship between the level of information disclosure and the type of auditor.

Thus, this variable will be defined as companies that are audited Big four, which assumes the value 1 and companies audited by other audit companies, where it assumes the value 0 .

Quotation has been considered an important indicator to measure the level of disclosure of companies, since more and more specific information is required by the $\mathrm{CMVM}^{3}$ to be available for the investors [12]. The use of derivative instruments has a significantly positive impact on companies' market value [14]. This could lead to an increase in the disclosure level on these instruments.

The companies under study are listed on the stock exchange, so it is considered interesting to study whether the level of disclosure of information about derivatives is dependent on a higher or lower quotation. Thus, quotation will be measured by the annual share price average of each of the companies.

Table 1 shows descriptive statistics of independent variables.

3 Securities Exchange Markets Commission. 
Table 1. Descriptive statistics.

\begin{tabular}{|c|c|c|c|c|c|c|c|c|}
\hline \multirow{2}{*}{ Company } & \multirow{2}{*}{$\mathbf{N}$} & \multicolumn{2}{|l|}{ Dimension } & \multicolumn{2}{|c|}{ Profitability } & \multirow{2}{*}{$\begin{array}{l}\text { Type of Auditor } \\
\%\end{array}$} & \multicolumn{2}{|c|}{ Quotation } \\
\hline & & Average & S. D & Average & S. D & & Average & S. D \\
\hline Altri & 51 & 1.230 .132 & 48.151 & 0,278 & 0,076 & 100 & 4,602 & 0,670 \\
\hline Corticeira Amorim & 51 & 754.500 & 103.887 & 0,190 & 0,048 & 100 & 8,249 & 2,187 \\
\hline CTT & 51 & 1.348 .311 & 246.174 & 0,233 & 0,075 & 100 & 6,269 & 2,678 \\
\hline EDP & 51 & 42.898 .587 & 1.052 .043 & 0,099 & 0,010 & 100 & 3,033 & 0,249 \\
\hline EDP Renováveis & 51 & 16.231 .476 & 499.200 & 0,039 & 0,017 & 100 & 6,751 & 0,635 \\
\hline F. Ramada & 51 & 241.477 & 63.799 & 0,242 & 0,127 & 100 & 6,977 & 3,079 \\
\hline Galp & 51 & 8.822 .659 & 6.572 .794 & 0,023 & 0,010 & 100 & 13,412 & 2,399 \\
\hline Ibersol & 51 & 367.109 & 109.160 & 0,133 & 0,047 & 100 & 11,184 & 1,976 \\
\hline Jerónimo Martins & 51 & 1.474 .270 & 106.372 & 0,272 & 0,068 & 100 & 14,310 & 2,133 \\
\hline Mota-Engil & 51 & 4.650 .207 & 448.653 & 0,100 & 0,021 & 33,3 & 2,399 & 1,106 \\
\hline Navigator Company & 51 & 2.426 .049 & 15.368 & 0,171 & 0,008 & 100 & 3,704 & 0,502 \\
\hline NOS & 51 & 2.975 .401 & 7.844 & 0,092 & 0,019 & 66,7 & 6,122 & 0,977 \\
\hline Pharol & 51 & 278.695 & 26.966 & $-1,900$ & 1,436 & 0 & 0,243 & 0,033 \\
\hline REN & 51 & 4.834 .818 & 459.309 & 0,092 & 0,007 & 100 & 2,653 & 0,156 \\
\hline Semapa & 51 & 4.047 .918 & 53.724 & 0,143 & 0,024 & 100 & 14,630 & 2,764 \\
\hline Sonae Capital & 51 & 530.179 & 38.786 & $-0,041$ & 0,128 & 100 & 0,715 & 0,191 \\
\hline Sonae & 51 & 5.447 .326 & 198.317 & 0,096 & 0,013 & 100 & 1,016 & 0,129 \\
\hline
\end{tabular}

Dimension $=$ Total Asset; Profitability=Net Income/Equity; Type of Auditor is equal to 1 if the company is audited for one of the Big-4, otherwise assumes the value 0 ; Quotation=value of the average annual share price quotation.

\section{Results Analysis}

After collecting the necessary information for the study and after selecting possible explanatory variables of the ID, the application of statistical tests follows, through SPSS software (Statistical Package for the Social Sciences). Thus, it is intended to study the level of dissemination of derivative financial instruments, taking into account all potential determinant factors.

\subsection{Level of Information Disclosure on Financial Instruments}

The results of the studies by Lemos and Rodrigues [8] and Lemos, Rodrigues and Ariza [9] indicate a low level of information disclosure on derivative financial instruments, by Portuguese companies. In this section, it is intended to examine whether the mandatory adoption of IAS/IFRS, namely IFRS 7, contributed to an increase in the amount of information disclosed. To measure companies' disclosure level (ID), we used the expression (1).

Table 2 shows the results of the ID variable.

Table 2. Disclosure index (ID) during the period 2015-2017.

\begin{tabular}{lllll}
\hline Company & $\mathbf{2 0 1 5}$ & $\mathbf{2 0 1 6}$ & $\mathbf{2 0 1 7}$ & Average \\
\hline Altri & 0,703 & 0,703 & 0,757 & 0,721 \\
Corticeira Amorim & 0,730 & 0,811 & 0,784 & 0,775 \\
CTT & 0,000 & 0,000 & 0,000 & 0,000 \\
EDP & 0,649 & 0,838 & 0,865 & 0,784 \\
EDP Renováveis & 0,892 & 0,919 & 0,946 & 0,919 \\
F. Ramada & 0,514 & 0,514 & 0,568 & 0,532 \\
Galp & 0,676 & 0,000 & 0,000 & 0,225 \\
Ibersol & 0,297 & 0,568 & 0,568 & 0,478 \\
Jerónimo Martins & 0,865 & 0,892 & 0,838 & 0,865 \\
\hline
\end{tabular}

\begin{tabular}{lllll}
\hline Company & $\mathbf{2 0 1 5}$ & $\mathbf{2 0 1 6}$ & $\mathbf{2 0 1 7}$ & Average \\
\hline Mota-Engil & 0,703 & 0,595 & 0,703 & 0,667 \\
Navigator Company & 0,811 & 0,838 & 0,865 & 0,838 \\
NOS & 0,730 & 0,676 & 0,784 & 0,730 \\
Pharol & 0,000 & 0,000 & 0,000 & 0,000 \\
REN & 0,811 & 0,757 & 0,784 & 0,784 \\
Semapa & 0,622 & 0,784 & 0,811 & 0,739 \\
Sonae Capital & 0,541 & 0,568 & 0,514 & 0,541 \\
Sonae & 0,703 & 0,730 & 0,757 & 0,730 \\
\hline
\end{tabular}

The results obtained show that a significant number of companies have an ID $>0.70$, which shows a considerable level of financial disclosure on financial instruments. These results do not meet the results of Lemos, Rodrigues and Ariza [9] which indicates that the mandatory adoption of IFRS 7 increased disclosure in Portuguese companies.

Yet, results also show that three of the companies had an ID equal to zero in any of the periods (CTT, Pharol and Galp). CTT and Pharol companies do not provide information on the disclosure of derivative financial instruments in any of the years under study. A Galp somente apresentou informação para o ano de 2015.

\subsection{Determinants of the Disclosure Index}

In this section, we present and discuss the results of the overall analysis of the period and for each of the years of the period.

We excluded from the study, CTT, Pharol and Galp companies, because they do not present information relevant to the ID.

Table 3 shows the results of spearman's Ordinal Correlation Coefficient for the period 2015 to 2017. 
Table 3. Spearman Correlation Coefficient (2015-2017).

\begin{tabular}{llllll}
\hline & ID & Dimension & Profitability & Quotation & Type of Auditor \\
\hline ID & 1 & $0,547^{* *}$ & 0,061 & 0,217 & 0,092 \\
Dimension & $0,547^{* *}$ & 1 & $-0,451$ & $-0,279$ & $-0,133$ \\
Profitability & 0,061 & $-0,451$ & 1 & 0,464 & 0,095 \\
Quotation & 0,217 & $-0,279$ & 0,464 & 1 & 0,194 \\
Type of Auditor & 0,092 & $-0,133$ & 0,095 & 0,194 & 1 \\
\hline
\end{tabular}

*The correlation is significant at a level of $5 \%$.

** The correlation is significant at a level of $1 \%$.

Considering a significance level of $1 \%$, the existence of a different correlation of zero between ID and the independent variable "Dimension" $(p$-value $<0.01)$ is concluded. These results show the existence of a positive relationship between size and information disclosure level on derivative financial instruments. The larger the size of the company, the higher the level of disclosure. This result goes against the conclusions of the studies by Lemos, Rodrigues and Ariza [9] and Malachi and Zambra [18].

In order to understand whether this relationship is visible in all the years of the study period, it is now important to study whether these correlations are identical to the different years of the period under study.

In the following tables (tables 4, 5 and 6) the results of spearman's correlation coefficient are presented, for each of the years of the period under study.

Table 4. Spearman Correlation Coefficient (year 2015).

\begin{tabular}{|c|c|c|c|c|c|}
\hline & ID & Dimension & Profitability & Quotation & Type of Auditor \\
\hline ID & 1 & 0,429 & 0,113 & 0,119 & 0,035 \\
\hline
\end{tabular}

*The correlation is significant at a level of $5 \%$.

** The correlation is significant at a level of $1 \%$.

Table 5. Spearman Correlation Coefficient (year 2016).

\begin{tabular}{lllll}
\hline & ID & Dimension & Profitability & Quotation \\
\hline ID & 1 & $0,575^{*}$ & 0,075 & 0,324 \\
\hline
\end{tabular}

*The correlation is significant at a level of 5\%

** The correlation is significant at a level of $1 \%$

Table 6. Spearman Correlation Coefficient (year 2017).

\begin{tabular}{llllll}
\hline & ID & Dimension & Profitability & Quotation & Type of Auditor \\
\hline ID & 1 & $0,625^{*}$ & $-0,095$ & 0,188 & $-0,035$ \\
\hline
\end{tabular}

*The correlation is significant at a level of $5 \%$.

** The correlation is significant at a level of $1 \%$.

According to the results of the previous tables, there is a positive relationship between the size of the company and the level of disclosure in 2016 and 2017 (pvalue $<0.05$ ). Observing the correlation coefficient, it is observed that the positive relationship between size and level of dissemination has been increasing over the 3 years.

In summary, presented results show a positive relationship of Dimension with disclosure level for the period (2015-2017). In the analysis per year there is an increase in the relationship between Dimension and disclosure level.

Thus, it is relevant to study the behavior of companies in a more disaggregated way. Given the results achieved by the Dimension variable, in the following section, the company's behavior, in terms of disclosure level according to their size will be studied.

\subsection{Disclosure Level Analysis by Groups of Companies, by Economic Period}

In this section, we intend to analyze the level of disclosure by groups of companies according to their size, since, when building the ID variable, the companies under study did not present homogeneous behavior. This objective arises due to the need to prove whether, among the companies under study, larger companies disclose more information.

Given the dimension differences among companies, it was necessary to create a hierarchy, that is, five groups (clusters) of companies were created ${ }^{4}$, so that it is possible to analyze each group's behavior.

Dividing the number of cases per cluster was performed using the Cluster Hierarchical Method, more specifically the Ward method. It is a method that allows the formation of groups by their degree of homogeneity [22].

The scatter plot presents the positioning of the companies, in each of the years, in the plane, taking into account the ID in relation to Dimension (figure 1).

\footnotetext{
${ }^{4}$ Cluster- [Group] Cluster analysis is used to classify cases into groups that are relatively homogeneous, forming groups called clusters; disponível em https://www.mvsolution.com/wp-content/uploads/SPSS-Tutorial-Cluster-Analysis .pdf.
} 


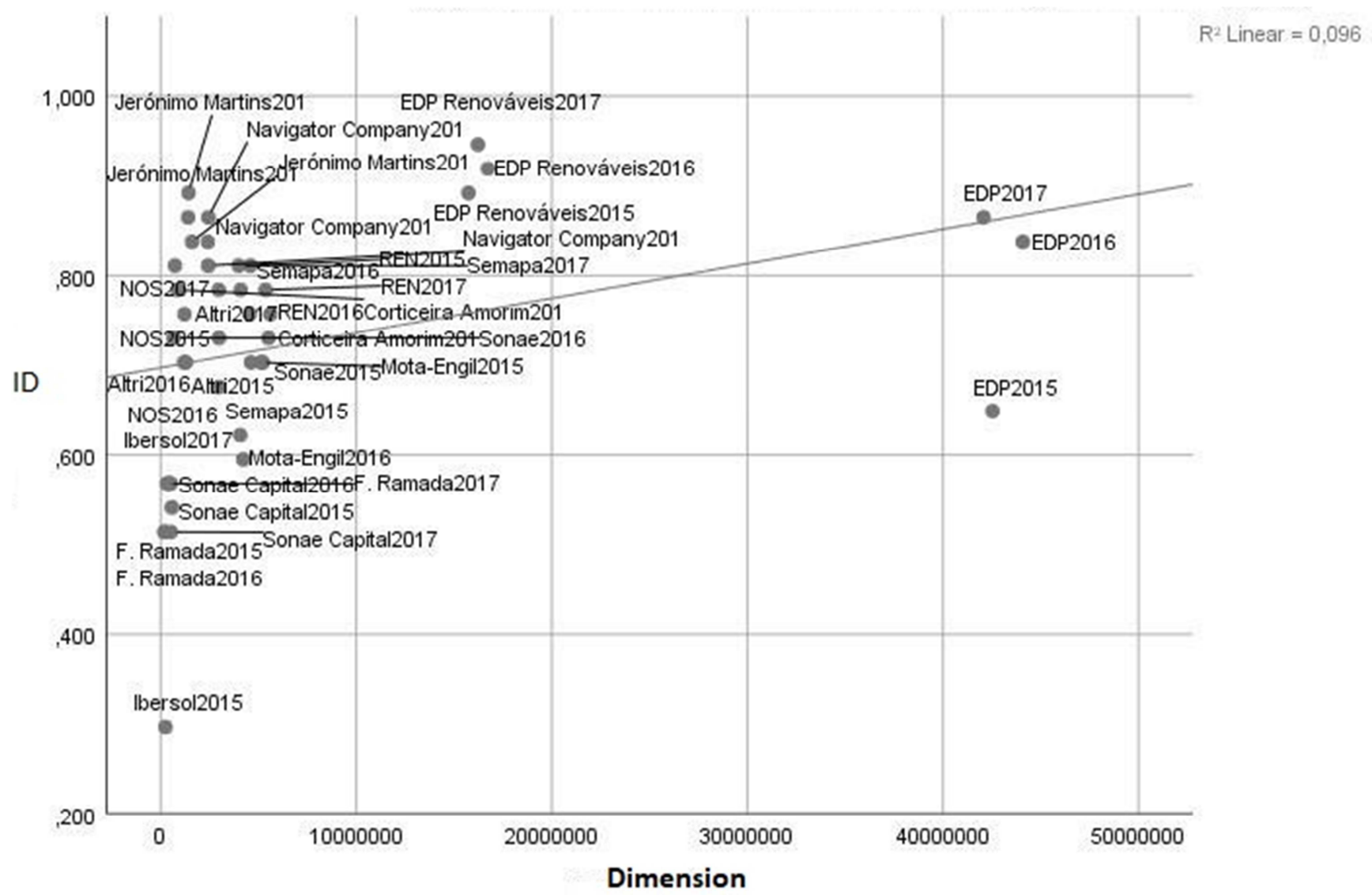

Figure 1. Scatter plot.

Analyzing figure 1 is considered that Edp and Edp Renewables can actually represent outliers, because they are companies with a very significant size compared to the remaining ones. For this reason, it is considered that the two companies should form two groups, separately from the remaining.

The fact that Ibersol, in 2015, stands out from the rest, happens because it only disclosed 11 parameters on derivative instruments, unlike the other years, in which it disclosed a greater number of information.

Thus, when observing the line present in the chart, we can see that there is a growing trend, that is, the larger the dimension, the greater the number of items disclosed.

Table 5 shows the results of each variable per cluster.

Table 7. Company's Clusters.

\begin{tabular}{|c|c|c|c|c|c|c|}
\hline \multirow{2}{*}{ Cluster } & \multirow{2}{*}{ Companies } & \multirow{2}{*}{$\mathbf{N}$} & \multicolumn{2}{|c|}{ Disclosure index (ID) } & \multicolumn{2}{|l|}{ Dimension } \\
\hline & & & Average & Error deviation & Average & Error deviation \\
\hline 1 & $\begin{array}{l}\text { Altri, Corticeira Amorim, Sonae Capital, F. } \\
\text { Ramada, Ibersol, Jerónimo Martins }\end{array}$ & 18 & 0,65 & 0,16 & 766.277 & 466840 \\
\hline 2 & EDP & 3 & 0,78 & 0,12 & 42.898 .587 & 1052043 \\
\hline 3 & EDP Renováveis & 3 & 0,92 & 0,03 & 16.231 .476 & 499200 \\
\hline 4 & Semapa, REN, Sonae, Mota-Engil & 12 & 0,73 & 0,07 & 4.745 .067 & 595258 \\
\hline \multirow[t]{2}{*}{5} & The Navigator Company, NOS & 6 & 0,78 & 0,07 & 2.700 .725 & 301090 \\
\hline & & Total $=42$ & & & & \\
\hline
\end{tabular}

Table 5 shows that the companies that belong to cluster 1 had the lowest average ID value (0.65), which is also the cluster of smaller companies. In contrast, Edp Renováveis (cluster 3) was the company with the highest ID value (0.92), but it is not the largest company. Edp (cluster 2) is the largest company, but does not have the highest level of disclosure.

Economic analysis aims to assess the existence of significant changes in disclosure level on derivative instruments, in different companies' clusters, over the tested period.

The following figures (figures 2, 3 and 4) show the dispersion of information (ID) for the five clusters, in the years 2015, 2016 and 2017, respectively. 


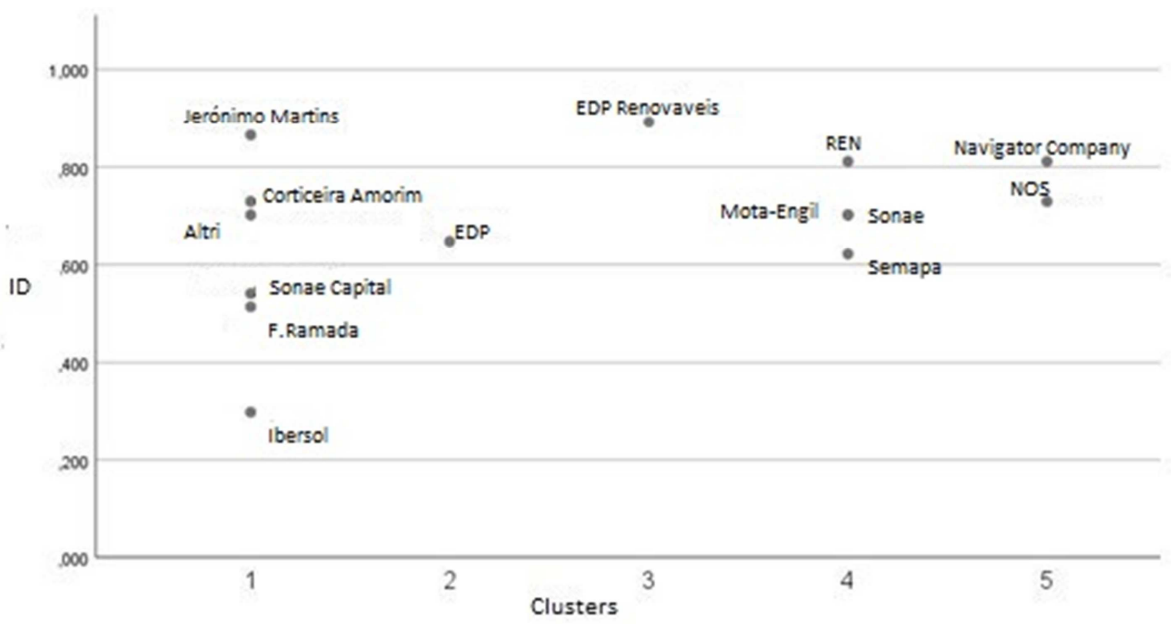

Figure 2. Cluster scatter plot - year 2015.

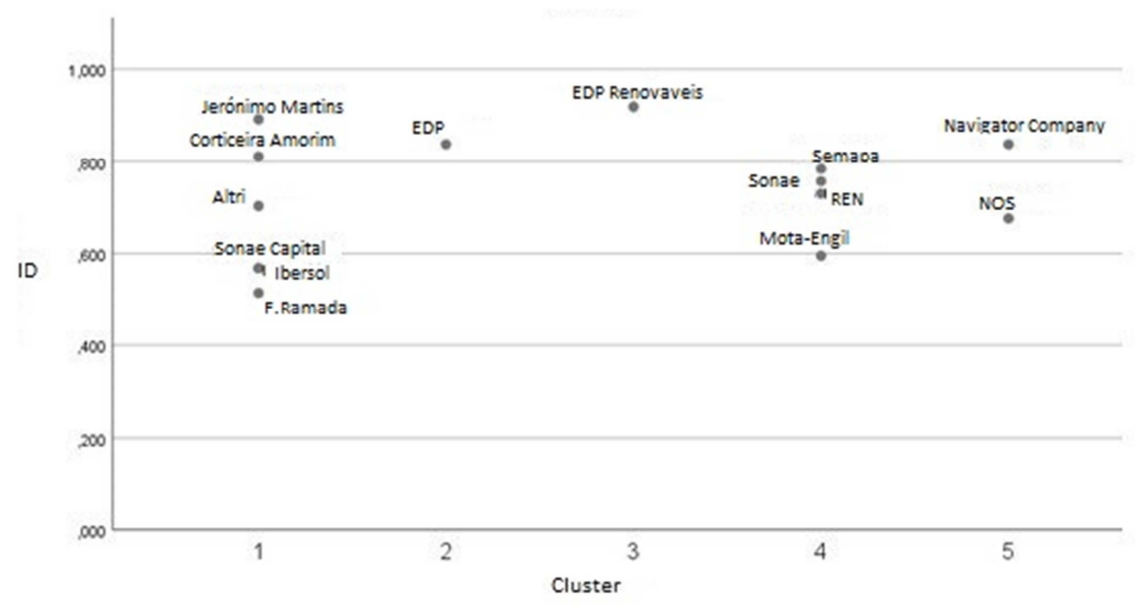

Figure 3. Cluster scatter plot - year 2016.

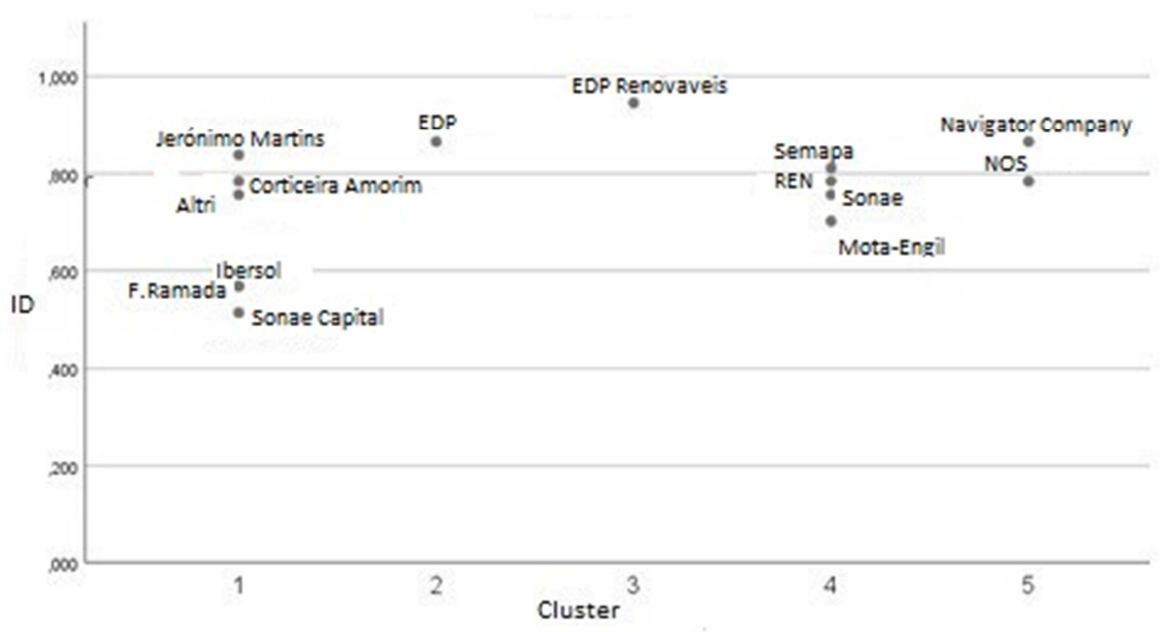

Figure 4. Cluster scatter plot - year 2017.

Through the analysis of the three figures, we can observe that the companies Jerónimo Martins, Edp, Edp Renováveis and The Navigator Company, were the companies that presented a higher ID in each of the years. Still, these companies present significant dimension differences. There is also a certain stability in most companies' ID. We can also note that, in all years, the companies that disclose the least are in cluster 1 , which confirms that it is the smallest companies that disclose the least. These results confirm the tendency that the larger the size of the company, the higher the level of information disclosure about derivative financial instruments. Nevertheless, despite this trend, it is possible to observe some 
disparity among companies in the same cluster and among clusters. Cluster 1 companies have significant ID amplitude differences. These results may be associated with the greater or lesser use of derivative financial instruments by companies, regardless of their size.

\section{Conclusion}

Derivative financial instruments have become increasingly judicious, which could therefore lead to an increase in levels of information disclosure, not only on the issue of derivative instruments, but also in all the financial information necessary in the analysis of the financial situation of the company, by third parties.

The present study was based on the analysis of the level of information disclosure on derivative financial instruments in the period 2015-2017, for those companies that make PSI 20 up, on the Euronext Lisbon stock exchange.

There was a positive relationship between disclosure index (ID) and the size of the companies. Through cluster analysis there was a trend for larger companies to disseminate more information compared to smaller companies. There was, on the other hand, a stability in ID values in most companies, over the period under analysis. Most companies in each cluster had ID higher than 0.70 , which indicates a substantial level of compliance with the disclosure requirements required by IFRS 7, regardless of the size of the company. These results are not coincident with the conclusions of Lemos, Rodrigues and Ariza [9] that evidenced a low disclosure level by Portuguese companies. This difference between both results may be related to the different periods under analysis. This evidence of an increase in Portuguese companies' disclosure level is related to the mandatory adoption of IAS/IFRS since 2005. However, these results may also reflect greater concern on the part of companies in disclosing this type of information, due to the negative impact that the global financial crisis has had on the performance of companies, in general.

The fact that the information contained in companies Reports and Accounts is often not explicit, may have constituted a lack of security in the analysis and verification of IFRS 7 requirements, which may condition presented conclusions.

\section{Appendix}

Table A1. Disclosure Index of information on derivative financial instruments by IFRS 7 standard.

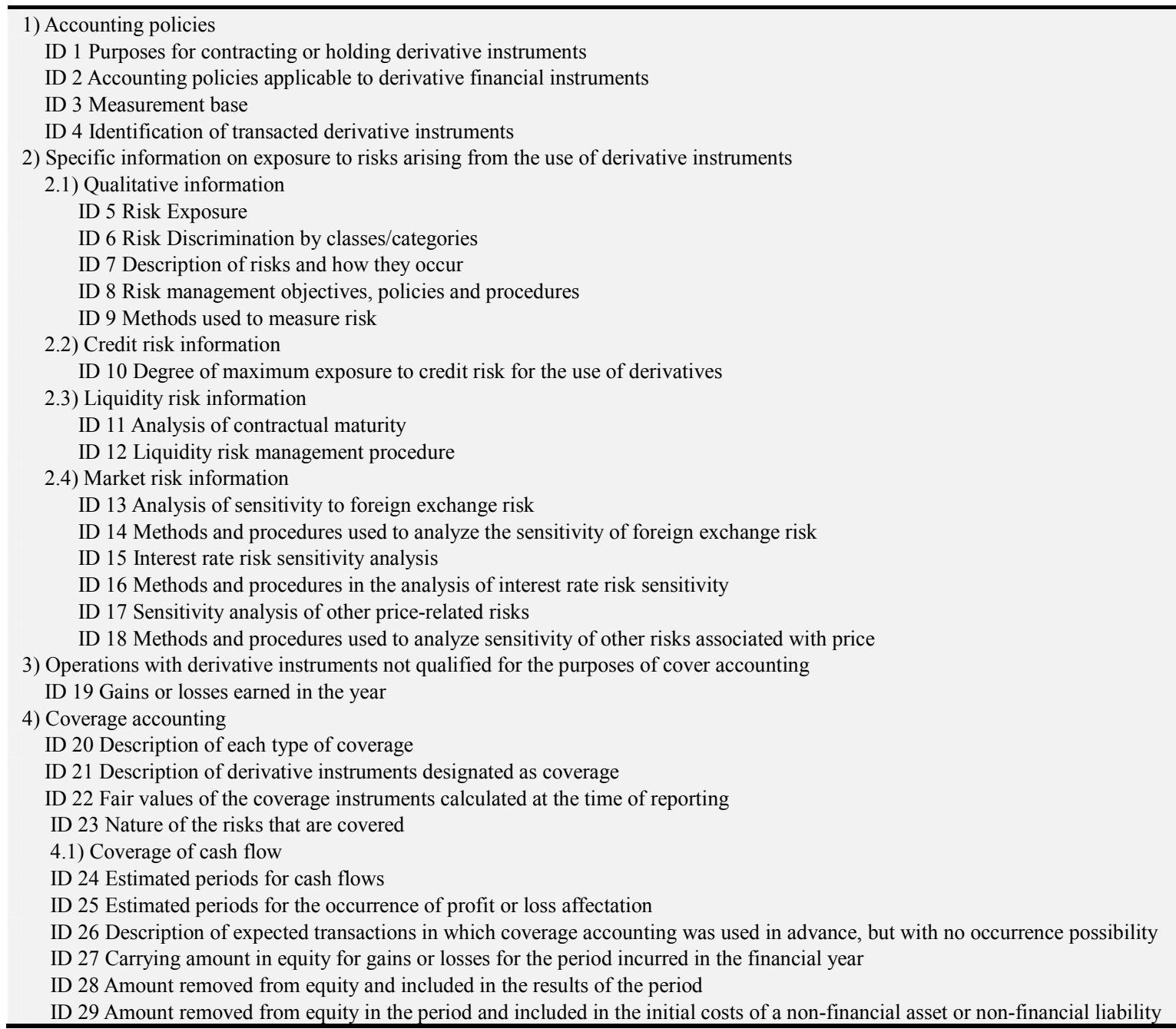


Which acquisition/occurrence is a planned and highly likely covered transaction

ID 30 Disclosure of the ineffectiveness recognized in profits and losses arising from the transaction

4.2) Fair value coverage

ID 31 Gains or losses of coverage made at fair value on the coverage instrument

ID 32 Gains or losses of coverage made at fair value on the item that was covered, attributable to the risk covered

4.3) Net investment coverage in foreign entities

ID 33 Ineffectiveness recognized in profits or losses arising from the transaction

5) Fair value

ID 34 Fair value of derivative instruments

ID 35 Methods and techniques for measuring fair value

ID 36 Assumptions applied to fair values' measurement

ID 37 Hierarchical level of fair value of derivative instruments

Source: Own elaboration based on the normative IFRS 7 and Lemos et al. (2009).

\section{References}

[1] International Accounting Standard Board (2016), IFRS 7 Financial Instruments: Disclosures, disponível em http://www.cnc.min-financas.pt/.

[2] Beaver, W. (1991). Financial Reporting: An Accounting Revolution; Prentice Hall.

[3] Regulation (EC) No 1606/2002 of the European Parliament and of the Council of 19 July 2002 on the application of international accounting standards.

[4] Regulation (EC) No 1725/2003 of 29 September 2003 adopting certain international accounting standards in accordance with Regulation (EC) No 1606/2002 of the European Parliament and of the Council.

[5] Regulation (EC) No 1126/2008 of 3 November 2008 adopting certain international accounting standards in accordance with Regulation (EC) No 1606/2002 of the European Parliament and of the Council.

[6] Marshall, A. P., Weetman, P. (2002), Information asymmetry in disclosure of foreign exchange risk management: can regulation be effective? Journal of Economics and Business. Vol. 54, 31-53.

[7] Darós, L.; Borba, J.; Junior, J. (2007), Verificação do cumprimento das normas sobre evidenciação de instrumentos financeiros derivativos nas demonstrações contábeis das empresas auditadas pelas Big Four; Congresso Universidade de São Paulo Controladoria e Contabilidade; São Paulo, https://congressousp.fipecafi.org/anais/artigos72007/543.pdf, consultado em 12-12-2019.

[8] Lemos, K.; Rodrigues, L. (2007), Divulgação de informação sobre operações com instrumentos derivados: Evidência empírica no mercado de capitais português; Tékhne-Revista de Estudos Politécnicos IV, 149-188.

[9] Lemos, K.; Rodrigues, L.; Ariza, L. (2009), Determinantes do nível de divulgação de informação sobre instrumentos derivados: Evidência empírica no mercado de capitais português; Tékhne-Revista de Estudos Politécnicos VII, 145-175.

[10] Resende, M. (2014). Principais determinantes das divulgações exigidas pela IFRS 7: O caso das empresas cotadas em Portugal; Mestrado- Contabilidade, Fiscalidade e Finanças Empresariais; ISEG; Lisboa, unpublished.

[11] Chalmers, K., Godfrey, J. (2004), Reputation costs: the impetus for voluntary derivative financial instrument reporting, Accounting, Organizations and Society 29, 95-125.

[12] Monteiro, S. (2007), Fatores explicativos do grau de divulgação ambiental em grandes empresas a operar em Portugal: Análise univariada; Instituto Politécnico do Cávado e do Ave; Ayala Calvo, J. C. y grupo de investigación FEDRA, Conocimiento, innovación y emprendedores: Camino al futuro.

[13] Filho, D.; Júnior, J. (2009). Desvendando os Mistérios do Coeficiente de Correlação de Pearson (r); Universidade Federal de Pernambuco (UFPE); Revista Política Hoje 18, 115-146.

[14] Giraldo-Prieto, C.; Uribe, G; Bermejo, C.; Herrera, D. (2017), Coberturas financieras con derivados y su incidencia en el valor de Mercado en empresas colombianas que cotizan en Bolsa; Contaduría y Administración 62; 1553-1571.

[15] Moura, G.; Dagostini, L.; Theis, M.; Klann, R. (2017), Fatores determinantes para utilização do Hedge em companhias abertas listadas na BM\&FBOVESPA; Contabilidade Vista \& Revista $28,101-120$.

[16] Hassan, M. (2004), The information quality of derivative disclosures in corporate annual reports of Australian firms in the extractive industries; University Kebangsaan Malaysia; M. Social Science (Southampton); School of Accountancy at Queensland University of Technology.

[17] Nunes, S. (2014). A divulgação sobre instrumentos derivados: Evidência empírica do setor da indústria português; Instituto Politécnico de Lisboa, Instituto Superior de Contabilidade e Administração de Lisboa (ISCAL); Lisboa; unpublished.

[18] Malaquias, R.; Zambra, P. (2017). Disclosure of financial instruments: Practices and challenges of Latin American firms from the mining industry; Research in International business and finance $45,158-167$.

[19] Ali, M., Kamran Ahmed, K., Henry, D. (2004), Disclosure compliance with national accounting standards by listed companies in South Asia, Accounting and Business Research 34, 183-199.

[20] Birt, J., Rankin, M., Song, C. (2013), Derivatives use and financial instrument disclosure in the extractives industry; Accounting and Finance 53, 55-83.

[21] Lan, Y.; Wang, L.; Zhang, X. (2013), Determinants and features of voluntary disclosure in the Chinese stock market; China Journal of Accounting Research 6, 265-285.

[22] Sharma, S. (1996), Applied multivariate techniques; Nova Iorque: John Wiley \& Sons. 